Pak. j. sci. ind. res. Ser. B: biol. sci. 201457 (3) 155-160

\title{
Impact of a Widely Cultivated Tree (Moringa oleifera) on the Health of Commercially Important Hybrid Catfish
}

\author{
Kabir Mohammed Adamu* and Idris Mohammed Ahmed \\ Department of Biology, Ibrahim Badamasi Babangida University, Lapai, P.M.B. 11, \\ Lapai, Niger State, Nigeria
}

(received January 31, 2014; revised July 10, 2014; accepted July 18, 2014)

\begin{abstract}
Plantations of the tree Moringa oleifera often lead to increas levels of leaf dust in nearby freshwater environments, and there is concern that, this could have a negative impact on catfish, which are important for aquaculture. Therefore, this study, determined the biochemical alterations in serum, liver and kidney of hybrid catfish (Clarias gariepinus $(\bigcirc) \times$ Heterobranchus bidorsalis $\left({ }^{\circ}\right)$ exposed to sub-lethal concentrations of $M$. oleifera leaf dust in a static renewable bioassay system during a medium term exposure period. The fish (mean length, $16.33 \mathrm{~cm}$, mean weight, $9.90 \mathrm{~g}$ ) were exposed to $0.16,0.12,0.08,0.04$ and $0.00 \mathrm{mg} / \mathrm{L}$ concentrations of the plant leaf dust in triplicate exposure. After 21-days of exposure period, the fish were sacrificed for the biochemical parameters: glucose, total protein, albumin, globulin, cholesterol, triglyceride, $\gamma$-glutamyltransferase, alanine aminotransferase, aspartate aminotransferase and lactate dehydrogenase. Fish exposed to leaf dust showed significant differences $(\mathrm{P}<0.05)$ in levels of gamma glutamyltransferase serum, liver and kidney, and also in levels of albumin and cholesterol $(\mathrm{P}<0.05)$, in the liver and kidney. The levels of glucose and triglycerides were significantly different $(\mathrm{P}<0.05)$, in the liver and kidney, respectively, while, the other parameters were not significantly different $(\mathrm{P}>0.05)$, in the liver and kidney, respectively, in the test fish. Other parameters were not significantly different $(\mathrm{P}>0.05)$ in their respective tissue-organs. Ipso-facto, the alteration in biochemical parameters of hybrid catfish exposed to $M$. oleifera leaf dust was concentration dependent with $0.16 \mathrm{mg} / \mathrm{L}$ showing the highest negative alterations thus fish exposed to concentrations above $0.16 \mathrm{mg} / \mathrm{L}$ for longer durations may suffer impaired health effects.
\end{abstract}

Keywords: biochemical parameters, hybrid catfish, Moringa oleifera

\section{Introduction}

Plant materials are virtually inexhaustible source of structurally diverse biologically active substance (Ujvary, 2000), where some plants contain compounds of various classes that have insecticidal, pesticidal and molluscidal properties. One of such plants is Moringa oleifera, commonly known as 'Zogalle' in northern Nigeria, and one of the most useful and widely cultivated tropical trees. According to Foidl et al. (2001) every part of this plant is used in traditional medicine. However, the plant has also been reported to have negative effects on the health of a variety of fish species, including Heterobranchus bidorsalis (Olufayo and Akinpelu, 2012), Nile tilapia, and Oreochromis niloticus (Ayotunde et al. 2010). The tree's components are also known to affect rats (Omobuwajo et al., 2011; Hamza, 2010; Tende et al., 2010; Oluduro and Aderiye, 2009; Ara et al., 2008; Jaiswal et al., 2007) and chicken (Ogbe and Affiku, 2012). Studies have also shown that the tree has the potential of insecticidal activity

*Author for correspondence; E-mail: kabrmoh@yahoo.com against Cnaphalacrosis medicinalis (Muralidhara Rao et al., 2010), as antimicrobial agent (Anwar and Rashid, 2007; Lockett et al., 2000) and treating human infectious disease (Arekemase et al., 2011).

According to Rand et al. (1995) in order to extrapolate meaningful, relevant and ecologically significant results in aquatic toxicity research, not only appropriate test but also appropriate organisms should be used. The hybrid catfish, Clarias gariepinus $(\bigcirc) \times H$. bidorsalis (ठ) is one of the commercially important species of fish for rapid aquaculture expansion in Nigeria and Africa, as they constitute one of the main fish species of economic importance. Thus, the study address the question of to what extent the health of catfish might be impacted by varying levels of leaf dust in the water, derived from M. oleifera, which are commonly planted near waters where catfish are held.

To assess fish health, some biochemical parameters were used to evaluate the functional capacity of several critical organ systems. The levels of these parameters: glucose, 
triglycerides, albumin, globulin, total protein, cholesterol, aspartate aminotransferase, alanine aminotransferase, lactate dehydrogenase, and $\gamma$-glutamyltransferase in blood, liver and kidney were used. Therefore, this study was aimed at ascertaining the effect of M. oleifera leaf dust on the selected biochemical parameters of hybrid catfish after a medium term, 21-day exposure period in a static semi renewable bioassay system; in order to monitor the health status and provide basic information on the effects of the M. oleifera leaf dust on the test fish.

\section{Materials and Methods}

Two hundred and twenty juveniles of hybrid catfish, mean \pm standard error total length and weight of $16.33 \pm$ $0.50 \mathrm{~cm}$ and $9.90 \pm 1.25 \mathrm{~g}$, respectively, were procured from Premier Fish Farm, Chanchaga, Niger State, Nigeria. The fish were held in Biology laboratory in large aquaria of $80 \mathrm{~L}$ capacity with clean borehole water for 3 weeks. Thereafter, they were transferred to the experimental plastic aquaria ( $8 \mathrm{fish} / 30 \mathrm{~L}$ aquarium) in three replications. The fish were fed $3.0 \mathrm{~mm}$ coppens fish feed twice daily during the acclimatisation and exposure periods. Leaves of M. oleifera were obtained from state low-cost housing estate, Lapai, Nigeria; which were air dried for 30 days, ground into powder, sieved and stored in a sealed plastic container for use. The concentrations of $M$. oleifera used for experiment $(0.16,0.12,0.08,0.04$ and $0.00 \mathrm{mg} / \mathrm{L})$ dust were ascertained after preliminary and acute toxicity tests investigations into what concentrations could realistically occur in the environment, where the catfish are typically held.

At the end of the 21-day exposure period, the fish were sacrificed to obtain blood, liver and kidney. Liver and kidney supernatants and serum were obtained from the sample following the procedures described by Adamu and Nwadukwe (2013). The selected biochemical parameters were determined in accordance to the standardised methods of the manufacturer's instruction manual of the commercial kits such as total protein- Biuret method (Tietz, 1995), albumin-bromocresol green method (Doumas et al., 1971), globulin-calculating method (total protein-albumin), triglycerides- enzymatic colorimetric endpoint method (Bucolo and David, 1973), cholesterol-enzymatic endpoint method (Trinder, 1969), lactate dehydrogenase-enzyme in organic synthesis method, glucose-enzymatic colorimetric endpoint method (Trinder, 1969), alanine and aspartate aminotransferases-enzymatic method (Reitman and Frankel, 1957) and $\gamma$-glutamyltransferase - enzymatic method (IFCC, 1983).
All results were presented as means \pm standard error. Data were analysed using two-way analysis of variance; thereafter, individual means were compared using Bonferroni comparison test. The differences were considered statistically significant at either $\mathrm{P}<0.01$ or $\mathrm{P}<0.05$. All statistical analyses were performed using the software package (graphpad prism@ software version 6.0 San Diego, CA, USA).

\section{Results and Discussion}

The plant leaf dust revealed varying levels of variations in the determined biochemical parameters as presented in Table 1 after the 21-days exposure period. With exception of globulin level in fish exposed to $0.16 \mathrm{mg} / \mathrm{L}$ plant leaf dust, the serum total protein, globulin, albumin, glucose, cholesterol and triglycerides were not significantly different $(\mathrm{P}>0.05)$, compared to the control. The levels of total protein, albumin and globulin were significantly different $(\mathrm{P}<0.05)$ in the liver whereby, the kidney recorded significant difference $(\mathrm{P}<0.05)$, as the concentration of the plant leaf dust increased. The liver recorded the higher significant difference $(\mathrm{P}<0.05)$, with the kidney recording the least and no significant difference in serum. With the exception of fish exposed to $0.16 \mathrm{mg} / \mathrm{L}$ of the plant leaf dust there was no significant difference $(\mathrm{P}>0.05)$ in liver cholesterol, similarly, the liver glucose and triglycerides were not significantly different $(\mathrm{P}>0.05)$. Significant difference $(\mathrm{P}<0.05)$ was recorded in kidney glucose, cholesterol and triglycerides as the concentrations of the plant leaf dust increased.

The activities of $\gamma$-glutamyltransferase and lactate dehydrogenase were not significantly different $(\mathrm{P}>0.05)$, in the serum of the test fish, however, there were varying levels of significant difference $(\mathrm{P}<0.05)$ in the enzymes activities in the liver and kidney as the concentrations of the plant leaf dust increased. The aminotransferases (aspartate and alanine) were significantly different $(\mathrm{P}<0.05)$ in the serum, liver and kidney of the test fish as the concentrations of the plant leaf dust increased.

The highest serum, liver and kidney alanine aminotransferase activity was recorded in fish exposed to 0.16 $\mathrm{mg} / \mathrm{L}$ of the plant leaf dust. According to Witthawaskul et al. (2003), the enzyme is remarkably specific for liver function; where it is found in particularly large amounts in the liver which plays an important role in metabolism. The significant higher activity of the enzyme may be an indication that the plant leaf dust stimulated the increased synthesis of the liver enzyme. As the 
Table 1. Mean value biochemical parameters of hybrid catfish exposed to concentrations of Moringa oleifera leaf dust after 21 days

\begin{tabular}{|c|c|c|c|c|c|c|}
\hline \multirow[t]{2}{*}{ Biochemical parameters } & \multirow{2}{*}{$\begin{array}{l}\text { Organ/ } \\
\text { Tissue }\end{array}$} & \multicolumn{5}{|c|}{ Concentration of $M$. oleifera leaf dust $(\mathrm{mg} / \mathrm{L})$} \\
\hline & & 0.00 & 0.04 & 0.08 & 0.12 & 0.16 \\
\hline \multirow[t]{3}{*}{ Total protein $(\mathrm{g} / \mathrm{dL})$} & Serum & $11.18(3.53)^{\mathrm{a}}$ & $10.52(0.48)^{\mathrm{a}}$ & $14.49(4.45)^{\mathrm{a}}$ & $12.11(2.09)^{\mathrm{a}}$ & $13.58(1.51)^{\mathrm{a}}$ \\
\hline & Liver & $7.77(0.19)^{\mathrm{a}}$ & $20.62(3.59)^{b^{*}}$ & $22.42(0.70)^{b^{*}}$ & $21.29(2.22)^{b^{*}}$ & $20.07(3.44)^{b *}$ \\
\hline & Kidney & $7.55(0.70)^{\mathrm{a}}$ & $7.44(0.06)^{\mathrm{a}}$ & $10.50(0.19)^{\mathrm{a}}$ & $14.27(1.15)^{b}$ & $17.77(1.26)^{b}$ \\
\hline \multirow[t]{3}{*}{ Albumin (g/dL) } & Serum & $6.82(1.16)^{\mathrm{a}}$ & $7.13(0.59)^{\mathrm{a}}$ & $9.36(1.44)^{\mathrm{a}}$ & $8.11(0.33)^{\mathrm{a}}$ & $11.42(1.28)^{\mathrm{a}}$ \\
\hline & Liver & $5.99(0.10)^{\mathrm{a}}$ & $10.74(2.52)^{b}$ & $8.59(0.49)^{b}$ & $15.60(0.98)^{b^{*}}$ & $11.21(2.37)^{\mathrm{b}}$ \\
\hline & Kidney & $3.99(0.64)^{\mathrm{a}}$ & $5.27(0.27)^{\mathrm{a}}$ & $7.65(0.32)^{b}$ & $8.65(1.47)^{\mathrm{b}}$ & $10.96(0.18)^{b}$ \\
\hline \multirow[t]{3}{*}{ Globulin (g/dL) } & Serum & $4.35(2.37)^{\mathrm{a}}$ & $3.38(1.08)^{\mathrm{a}}$ & $5.12(1.02)^{\mathrm{a}}$ & $3.99(1.76)^{\mathrm{a}}$ & $2.16(0.23)^{b}$ \\
\hline & Liver & $1.79(0.10)^{\mathrm{a}}$ & $9.87(1.06)^{b^{*}}$ & $8.84(2.20)^{\mathrm{b*}}$ & $5.69(1.20)^{\mathrm{b}}$ & $8.86(1.81)^{\mathrm{b}^{*}}$ \\
\hline & Kidney & $3.56(0.07)^{\mathrm{a}}$ & $2.18(0.33)^{\mathrm{a}}$ & $2.86(0.52)^{\mathrm{a}}$ & $5.62(0.33)^{\mathrm{a}}$ & $6.81(1.44)^{\mathrm{b} *}$ \\
\hline \multirow[t]{3}{*}{ Glucose (mg/dL) } & Serum & $152.15(11.65)^{\mathrm{a}}$ & $160.65(3.45)^{\mathrm{a}}$ & $153.30(10.60)^{\mathrm{a}}$ & $173.05(16.05)^{\mathrm{a}}$ & $168.05(0.95)^{\mathrm{a}}$ \\
\hline & Liver & $164.40(5.10)^{\mathrm{a}}$ & $166.60(10.50)^{\mathrm{a}}$ & $166.80(0.70)^{\mathrm{a}}$ & $185.90(1.80)^{\mathrm{a}}$ & $187.05(2.55)^{\mathrm{a}}$ \\
\hline & Kidney & $129.20(25.60)^{\mathrm{a}}$ & $189.25(1.25)^{\mathrm{b}}$ & $179.95(13.85)^{b}$ & $176.05(5.65)^{b}$ & $193.10(1.70)^{b}$ \\
\hline \multirow[t]{3}{*}{ Cholesterol (mmol/L) } & Serum & $6.08(0.08)^{\mathrm{a}}$ & $6.01(0.19)^{\mathrm{a}}$ & $6.17(0.21)^{\mathrm{a}}$ & $9.73(2.58)^{\mathrm{a}}$ & $7.47(0.36)^{\mathrm{a}}$ \\
\hline & Liver & $7.61(1.25)^{\mathrm{a}}$ & $6.99(0.33)^{\mathrm{a}}$ & $7.70(1.60)^{\mathrm{a}}$ & $9.95(0.55)^{\mathrm{a}}$ & $15.27(0.16)^{\mathrm{b} *}$ \\
\hline & Kidney & $7.08(1.26)^{\mathrm{a}}$ & $9.23(0.11)^{\mathrm{a}}$ & $8.57(1.21)^{\mathrm{a}}$ & $11.42(1.55)^{b^{*}}$ & $13.25(2.18)^{\mathrm{b} *}$ \\
\hline \multirow[t]{3}{*}{ Triglycerides (mmol/l) } & Serum & $11.12(1.05)^{\mathrm{a}}$ & $9.98(0.93)^{\mathrm{a}}$ & $10.61(0.38)^{\mathrm{a}}$ & $10.70(0.16)^{\mathrm{a}}$ & $10.60(0.11)^{\mathrm{a}}$ \\
\hline & Liver & $10.13(0.29)^{\mathrm{a}}$ & $9.79(2.19)^{\mathrm{a}}$ & $9.10(0.98)^{\mathrm{a}}$ & $8.00(0.32)^{\mathrm{a}}$ & $8.35(0.47)^{\mathrm{a}}$ \\
\hline & Kidney & $6.66(0.10)^{\mathrm{a}}$ & $9.14(0.46)^{\mathrm{a}}$ & $8.99(1.53)^{\mathrm{a}}$ & $10.19(1.11)^{\mathrm{b}}$ & $11.91(1.27)^{b}$ \\
\hline \multirow[t]{3}{*}{$\gamma$-glutamyltransferase $(\mu \mathrm{kat} / \mathrm{L})$} & Serum & $8.34(2.78)^{\mathrm{a}}$ & $18.21(7.09)^{\mathrm{b}}$ & $25.89(1.30)^{\mathrm{b}^{*}}$ & $25.41(8.73)^{b}$ & $35.45(2.31)$ \\
\hline & Liver & $8.91(0.38)^{\mathrm{a}}$ & $20.09(5.93)^{b^{*}}$ & $28.36(1.28)^{b^{*}}$ & $34.84(0.73)^{c^{*}}$ & $35.97(1.08)^{\mathrm{c}}$ \\
\hline & Kidney & $9.82(1.30)^{\mathrm{a}}$ & $10.61(0.56)^{\mathrm{a}}$ & $18.34(0.18)^{\mathrm{b}}$ & $24.82(0.74)^{\mathrm{c}}$ & $35.97(1.08)^{\mathrm{C}}$ \\
\hline \multirow[t]{3}{*}{ Lactate dehydrogenase $(\mu \mathrm{kat} / \mathrm{L})$} & Serum & $1.42(0.34)^{\mathrm{a}}$ & $1.62(1.35)^{\mathrm{a}}$ & $1.42(0.20)^{\mathrm{a}}$ & $1.75(0.54)^{\mathrm{a}}$ & $1.55(0.07)^{\mathrm{a}}$ \\
\hline & Liver & $2.02(0.81)^{\mathrm{a}^{*}}$ & $3.38(0.55)^{b^{*}}$ & $4.45(1.21)^{\mathrm{c}^{*}}$ & $2.90(1.42)^{\mathrm{a}^{*}}$ & $3.17(0.47)^{\mathrm{b} *}$ \\
\hline & Kidney & $3.27(1.13)^{\mathrm{a}^{*}}$ & $3.04(1.15)^{\mathrm{a}^{*}}$ & $2.23(0.47)^{\mathrm{b}}$ & $1.35(1.21)^{\mathrm{b}}$ & $0.41(0.27)^{\mathrm{c}^{*}}$ \\
\hline \multirow[t]{3}{*}{ Alanine aminotransferase $(\mu \mathrm{kat} / \mathrm{L})$} & Serum & $0.47(0.14)^{\mathrm{a}}$ & $0.64(0.03)^{\mathrm{a}}$ & $0.56(0.06)^{\mathrm{a}}$ & $0.77(0.17)^{\mathrm{b}}$ & $0.79(0.04)^{\mathrm{b}}$ \\
\hline & Liver & $0.23(0.00)^{\mathrm{a}^{*}}$ & $0.32(0.04)^{\mathrm{a}^{*}}$ & $0.29(0.06)^{\mathrm{a}^{*}}$ & $0.33(0.06)^{\mathrm{a}^{*}}$ & $0.42(0.08)^{\mathrm{b} *}$ \\
\hline & Kidney & $0.14(0.03)^{\mathrm{a}^{*}}$ & $0.26(0.04)^{\mathrm{a}^{*}}$ & $0.44(0.00)^{b}$ & $0.57(0.03)^{b}$ & $0.63(0.13)^{\mathrm{b}}$ \\
\hline \multirow[t]{3}{*}{ Aspartate aminotransferase $(\mu \mathrm{kat} / \mathrm{L})$} & Serum & $0.50(0.17)^{\mathrm{a}}$ & $0.61(0.05)^{\mathrm{a}}$ & $0.59(0.29)^{\mathrm{a}}$ & $0.75(0.03)^{\mathrm{b}}$ & $0.84(0.12)^{b^{*}}$ \\
\hline & Liver & $0.26(0.09)^{\mathrm{a}^{*}}$ & $0.58(0.14)^{b}$ & $0.56(0.11)^{b}$ & $0.73(0.22)^{b}$ & $0.59(0.08)^{b}$ \\
\hline & Kidney & $0.44(0.22)^{\mathrm{a}}$ & $0.53(0.14)^{\mathrm{a}}$ & $0.83(0.06)^{b^{*}}$ & $0.75(0.08)^{b}$ & $0.58(0.14)^{\mathrm{a}}$ \\
\hline
\end{tabular}

Standard error in parentheses, different superscript means $\mathrm{P}<0.05$ across the row, while *means $\mathrm{P}<0.05$ down the column.

activity of the enzyme increased in the liver, there was a corresponding increased enzyme activity in the serum, which may have been caused by leakage of the enzyme into the blood thereby, recording the higher activity in the serum. The serum as connective tissue, functions in transporting of this enzyme to the kidney for excretion. The increase in serum and kidney enzyme activity in hybrid catfish exposed to $M$. oleifera leaf dust was similar to that reported by Adamu (2009), when hybrid catfish was exposed to tobacco (Nicotiana tobaccum) leaf dust. By and large, the increase in kidney alanine aminotransferase activity may be due to the ability of the fish to maintain its homeostasis thereby, transporting the enzyme from the serum to the kidney for excretion.
The increase in the kidney aspartate aminotransferase activity as the concentrations of the plant leaf dust increased may be attributed to the potency of the plant leaf dust; as the enzyme is specific in kidney function (Witthawaskul et al., 2003). This is similar to the report of Adamu (2009) in hybrid catfish exposed to tobacco leaf dust. This increase may be indications that possibly the plant leaf dust with insecticidal, pesticidal and molluscidal properties may lead to an increase in this enzyme in the kidney. On the other hand, the increase of the enzyme in the serum may be attributed to the process of either deamination or transamination caused by the plant leaf dust. This is similar to the report of Tiwari and Singh (2004), that oleander (Nerium indicum) leaf dust increased the serum aspartate 
aminotransferase of fish. According to Hayes et al. (1989), increase in the activities of transaminases (ALT and AST) in serum is an indication for liver damage and function. The activities of these enzymes recorded in this study may be indicative of initial cell injury occurring in advance of gross hepatic pathology.

This study revealed that lactate dehydrogenase was insignificantly higher in serum. The higher activity of the enzyme in the liver corresponds to the higher glucose level in the liver for metabolic function. According to Boily et al. (2006) the enzyme is present in almost all body tissues as it plays an important role in cellular respiration. The report of Ceron et al. (1997) revealed that the enzyme is released from the liver after its cellular damage resulting to its higher presence in the serum and other organs. This is not the case in this study as the activity was less in serum and kidney. Therefore, the increased liver lactate dehydrogenase may be due to an alternative aerobic glycolytic pathway in conversion of lactate to pyruvate for the production of glucose, which is a major source of energy during stress (Kori-Siakpere, et al., 2012). $\gamma$-glutamyltransferase is an enzyme which is found in hepatocytes and biliary epithelial cells. The enzyme activity in the serum provides a very sensitive indicator of the presence or absence of hepatobiliary disease. This activity is significantly higher compared to the control, however, levels are within the range of its activity in hybrid catfish (Adamu and Nwadukwe, 2013) except in fish exposed to $0.16 \mathrm{mg} / \mathrm{L}$. This has further shown that the plant leaf dust at the highest concentration used in the study impedes the proper functioning ability of the liver.

The significantly higher liver total protein level recorded in the test fish exposed to M. oleifera leaf dust is an indication of hyperactivity of the liver that may be attributed to the plant leaf dust as the increase in aminotransferases activities may have affected amino acid metabolism and consequently the intermediates of gluconeogenesis. Adamu et al. (2013) reported increased liver total protein in hybrid catfish exposed to Jatropha curcas, which may be due to haemo-concentration arising from the plant leaf dust. This may have been the reason for the recorded high kidney total protein in fish exposed to this plant leaf dust. Another important protein in the body is the albumin which functions in maintaining the water balance in serum, transport and store a wide variety of compounds. It is responsible for about $80 \%$ of total osmotic regulation. As the concentrations of the plant leaf dust increased the level of serum, liver and kidney albumin increased. This may be an indication that the plant leaf dust may have been responsible for the high albumin values recorded. This is also evidenced by the recorded globulin level; as it transports varieties of substances such as lipid and inorganic ions. The insignificant decreased triglyceride level recorded in the liver showed that globulin was readily available to transport them.

The insignificant hyperglycaemia recorded in this study, may be attributed to the presence of the plant leaf dust as Fletcher (1975) reported that hyperglycaemia is associated with stressful situation. The content of serum glucose in cultured fish is dependent on the type of carbohydrate feed (Adamu and Kori-Siakpere, 2011). Glucose is transported from the liver to body cells via the bloodstream and is made available for cell absorption via the hormone insulin. The fish exposed to the plant leaf dust showed higher kidney glucose values, which may be an indication of liver dysfunction as the indicator enzymes (aminotransferases) have shown. Banaee et al. (2008) and Agrahari et al. (2007) have reported hyperglycaemia in fish exposed to toxicants. Cholesterol is the principal sterol synthesised by animals; in vertebrates it is formed predominantly in the liver. The hypercholesterolemia recorded in this study may be attributed to the effect of plant leaf dust as Parrier et al. (1972) reported that stress or pollution may lead to hypercholesterolemia in fish. Another fatty acid substance found in animal body is triglycerides (Cornel et al., 1988). During exposure periods, the role of glyceride as glucose precursor becomes more important as the liver metabolism also changes (Adamu and Kori-Siakpere, 2011). The decrease in liver triglyceride may be due to the presence of high liver glucose, since the liver does not stop the synthesis of glucose. Present studies have shown the diverse importance of Moringa oleifera. It is therefore, necessary to use the plant with caution as concentrations of $0.16 \mathrm{mg} / \mathrm{L}$ and above may have debilitating effects on the biochemical parameters of hybrid catfish after the 21-days exposure period reducing their yield and possible death.

\section{References}

Adamu, K.M., Nwadukwe, F.O. 2013. Growth and physiological profiles of hybrid catfish fed practical diet in different water regimes. Wayamba Journal of Animal Science, 5: 743-752.

Adamu, K.M., Isah, M.C., Baba, T.A., Idris, T.M. 2013. Selected liver and kidney biochemical profiles of hybrid catfish exposed to Jatropha curcas leaf dust. 
Croatian Journal of Fisheries, 71: 25-31.

Adamu, K.M., Kori-Siakpere, O. 2011. Effect of sublethal concentrations of tobacco (Nicotiana tobaccum) leaf dust on some biochemical parameters of hybrid catfish (Clarias gariepinus and Heterobranchus bidorsalis). Brazilian Archives of Biology and Technology, 54: 183-196.

Adamu, K.M. 2009. Sublethal effects of tobacco (Nicotiana tobaccum) leaf dust on enzymatic activities of Heteroclarias (a hybrid of Heterobranchus bidorsalis and Clarias gariepinus). Jordan Journal of Biological Sciences, 2: 151- 158.

Agrahari, S., Pandey, K.C., Gopal, K. 2007. Biochemical alteration by monococrophos in the blood plasma of fish, Channa punctatus (Bloch). Pesticide Biochemistry and Physiology, 88: 268-272.

Anwar, F., Rashid, U. 2007. Physico-chemical characteristics of Moringa oleifera seeds and seed oil from a wild provenance of Pakistan. Pakistan Journal of Botany, 39: 1443-1453.

Ara, N., Rashid, M., Amran, Md.S. 2008. Comparison of Moringa oleifera leaves extract with atenolol on serum triglyceride, serum cholesterol, blood glucose, heart weight, body weight in adrenaline induced rats. Saudi Journal of Biological Sciences, 15: 253-258.

Arekemase, M.O., Kayode, R.M.O., Ajiboye, A.E. 2011. Antimicrobial activity and phytochemical analysis of Moringa oleifera plant against some selected microorganisms. International Journal of Biology, 3: $52-59$.

Ayotunde, E.O., Fagbenro, O.A., Adebayo, O.T. 2010. Toxicity of aqueous extract of Moringa oleifera seed powder to Nile tilapia Oreochromis niloticus (Linne, 1779) fingerlings. International Research Journal of Agricultural Science and Soil Science, 1: 142-150.

Banaee, M., Mirvagefei, A.R., Rafei, G.R., Majazi, A.B. 2008. Effect of sub-lethal diazinon concentrations on blood plasma biochemistry. International Journal of Environmental Research, 2: 189-198.

Boily, F., Beaudoin, S., Measures, L.N. 2006. Hematology and serum chemistry of harp (Phoco groenlandica) and hooded seals (Cystophora cristata) during the breeding season, in Gulf of St. Lawrence, Canada. Journal of Wild Life Diseases, 42: 115-132.

Bucolo, G., David, H. 1973. Quantitative determination of serum triglycerides by the use of enzymes. Clinical Chemistry, 19: 476-482.

Ceron, J.J., Sancho, E., Ferrando, M.D., Gutierrez, C.,
Andreu, E. 1997. Changes in carbohydrate metabolism in the eel Anguilla anguilla during short term exposure to diazinon. Toxicological and Environmental Chemistry, 60: 201-210.

Cornel, L.H., Duffield, D.S., Joseph, B.E., Stark, B. 1988. Hematology and serum chemistry value in the beluga (Delphinapterus leucas). Journal of Wildlife Diseases, 24: 220-224.

Doumas, B.T., Watson, W.A., Biggs, H.C. 1971. Albumin standards and management of serum albumin with bromocresol green. Clinica Chimica Acta, 31: 87-96.

Fletcher, G.L. 1975. The effects of capture 'stress' and storage of whole blood on red blood cells, plasma protein, glucose and electrolytes of the winter flounder (Pseudopleuronectes americanus). Canadian Journal of Zoology, 53: 197-206.

Foidl, N., Makkar, H.P.S., Becker, K. 2001. The potential of Moringa oleifera for agricultural and industrial uses. In: The Miracle Tree: The Multiple Uses of Moringa, L.J. Fuglie (ed.), pp. 45-76, Church World Service, Dakar, Senegal.

Hayes, R.B., Sheffet, A., Spirtas, R. 1989. Cancer mortality among a cohort of chromium pigment workers. American Journal of Industrial Medicine, 16: 127-133.

Hamza, A.A. 2010. Ameliorative effects of Moringa oleifera Lam seed extract on liver fibrosis in rats. Food Chemistry and Toxicology, 48: 345-355.

IFCC, 1983. Methods for the measurement of catalytic concentration of enzymes, Part 4: IFCC methods for $\gamma$-glutamyltransferase. Journal of Clinical Chemistry and Clinical Biochemistry, 21: 643-646.

Jaiswal, D., Kumar Rai, P., Kumar, A., Metha, S., Watal, G. 2009. Effect of Moringa oleifera Lam. leaves aqueous extract therapy on hyperglycemic rats. Journal of Ethnopharmacology, 123: 392-396.

Kori-Siakpere, O., Adamu, K.M., Okobi, I.J. 2012. Sublethal effects of chromium on enzymatic activities of the African catfish: Clarias gariepinus (Burchell, 1822). Notulae Scientia Biologicae, 4: 24-30.

Lockeett, C.T., Calvert, C.C., Grivetti, L.E. 2000. Energy and micronutrient composition of dietary and medicinal wild plants consumed during drought: Study of rural Fulani, northeastern Nigeria. International Journal of Food Science and Nutrition, 51: 195-208.

Muralidhara Rao, D., Anithal, S., Aravinda, A., Karunakai, B., Devanna, N. 2010. Pharmaceutical investigation and biopesticidal activity of Jatropha curcas L. seed oil on digestive enzymatic profiles of Cnaphalacrosis 
medinalis (Rice leaffolder) and (Helicoverpa amnigera (cotton boll worm). International Research Journal of Pharmacy, 1: 194-200.

Ogbe, A.O., Affiku, J.P. 2012. Effect of polyherbal aqueous extracts (Moringa oleifera, Gum Arabic and wild Ganoderma lucidum) in comparison with antibiotic on growth performance and haematological parameters of broiler chicken. Research Journal of Recent Sciences, 1: 10-18.

Oluduro, A.O., Aderiye, B.I. 2009. Effect of Moringa oleifera seed extract on vital organs and tissue enzymes activities of male albino rats. African Journal of Microbiology, 3: 537-540.

Olufayo, M., Akinpelu, O. 2012. Haematology and Gill pathology of Heterobranchus bidorsalis Exposed to sub lethal concentration of Moringa oleifera leaf extract. Journal of Agriculture and Biodiversity Research, 1: 18-24.

Olugbemi, T.S., Mutayoba, S.K., Lekule, F.P. 2010. Moringa oleifera leaf meal as a hypocholesterolemic agent in laying hen diets. Livestock Research for Rural Development, 22: Article no. 84. http://www. Irrd22/4/olug22084.htm.

Omobuwajo, O.R., Alade, G.O., Akanmu, M.A., Obuotor, E.M., Ossan, S.A. 2011. Microscopic and toxicity studies on the leaves of Jatropha tanjorensis. Journal of Pharmacy and Pharmacology, 5: 12-17.

Perrier, H., Perrier, C., Gudefin, Y., Gras, J. 1972. Adrenaline-induced hypercholesterolemia in the rainbow trout (Salmo gairdneri Richardson): a separate study in male and female trout and the effect of adrenergic blocking agents. Comparative Biochemistry and Physiology, Part A: Physiology, 43A: 341-347.
Rand, G.M., Well, P.G., Mc Carthy, L.S. 1995. Introduction to aquatic toxicology. In: Fundamentals of Aquatic Toxicology: Effects, Environmental Fate, and Risk Assessment, G.M. Rand (ed.), Taylor and Francis, Washington, DC., USA.

Reitman, S., Frankel, S. 1957. A Colorimetric method for the determination of serum glutamic oxalacetic and glutamic pyruvic transaminases. American Journal of Clinical Pathology, 28: 56-63.

Tende, J.A., Ezekiel, I., Dikko, A.A.U., Goji, A.D.T. 2010. Effect of ethanolic leaves extract on blood glucose levels of Streptozocin induced diabetics and normoglycemic wistar rats. British Journal of Pharmacology and Toxicology, 2: 1-4.

Tietz, N.W. 1995. Clinical Guide to Laboratory Tests, pp. 518-519, $3^{\text {rd }}$ edition, W.B. Saunders, Philadelphia, PA., USA.

Tiwari, S., Singh, A. 2004. Piscicidal activity of alcoholic extract of Nerium indicum leaf and their biochemical stress response on fish metabolism. African Journal of Traditional Complementry and Alternative Medicines, 1: 15-29.

Trinder, P. 1969. Determination of glucose in blood using glucose oxidase with an alternative oxygen acceptor. Annals of Clinical Biochemistry, 6: 24-25.

Ujvary, I. 2000. Semi-natural products and related substances as alleged botanical pesticides. Pest Management Science, 56: 703-705.

Witthawaskul, P., Panthong, A., Kanjanerpothi, D., Taesothikul, T., Lertprasertsuike, N. 2003. Acute and sub acute toxicities of saponin mixture isolated from Schefflera leucantha viguier. Journal of Ethnopharmacology, 89: 115-121. 